DOI: $10.14720 /$ aas.2016.107.2.10

Agrovoc descriptors: Oganic fertilizers, inorganic fertilizers, turf, lawn grasses, fertilizer application, growth, production

Agris category code: F04, f01

\title{
The comparison of organic and inorganic fertilizers influence on selected indicators of turf growth-production process
}

\author{
Peter HRIC ${ }^{1}$, Ján JANČOVIČ ${ }^{2}$, Peter KOVÁR ${ }^{1}$, L’uboš VOZÁR ${ }^{3}$
}

Received March 24, 2016; accepted August 17, 2016.

Delo je prispelo 24. marca 2016, sprejeto 17. avgusta 2016.

\begin{abstract}
The aim of this experiment was to compare the influence of organic and inorganic fertilizers on selected indicators of turf growth-production process under non-irrigated conditions. The experiment was carried out in warm and dry conditions in the area of Nitra (Slovak Republic). In the experiment were included 5 treatments: 1.Without fertilization, 2. Turf NPK fertilizer $15-3-8(+3 \mathrm{MgO}+0.8 \mathrm{Fe}+18 \mathrm{~S})$, 3. Slow release NPK fertilizer $14-5-14(+4 \mathrm{CaO}+4 \mathrm{MgO}+7 \mathrm{~S})$, 4. Organic NPK fertilizer 5-1-1 and 5. Organic NPK fertilizer 3-2-1. Determination of the average height of turf, total height of turf and the annual average daily gain of height showed that best treatment was application of slow release fertilizer. Turf fertilized by Organic NPK fertilizer 5-1-1 reached the highest values of the average height of turf, total height of turf and the annual average daily gain of height, the same as treatment without fertilization. These finding were statistically significant. Treatment without fertilization reached the lowest values in evaluated growth-production parameters.
\end{abstract}

Key words: turf, fertilizing, organic fertilizers, inorganic fertilizers, growth-production process

\author{
IZVLEČEK \\ PRIMERJAVA VPLIVA ORGANSKIH IN \\ MINERALNIH GNOJIL NA IZBRANE KAZALNIKE \\ RASTI IN PRIDELKA TRAVNE RUŠE
}

Namen tega poskusa je bil primerjati vpliv gnojenja $\mathrm{z}$ organskimi in mineralnimi gnojili na izbrane kazalnike rasti in pridelka travne ruše $\mathrm{v}$ razmerah brez namakanja. Poskus je potekal $\mathrm{v}$ toplih in sušnih razmerah na območju Nitre (Republika Slovaška). V poskus je bilo vključenih 5 obravnavanj: 1. Brez gnojenja, 2. Gnojenje ruše z NPK gnojili v razmerju 15-3-8 (+3 $\mathrm{MgO}+0.8 \mathrm{Fe}+18 \mathrm{~S}), 3$. Gnojenje $\mathrm{z}$ gnojili s počasnim sproščanjem NPK hranil 14-5-14 $(+4 \mathrm{CaO}$ $+4 \mathrm{MgO}+7 \mathrm{~S}), 4$. Gnojenje $\mathrm{z}$ organskimi NPK gnojili $\mathrm{v}$ razmerju 5-1-1 in 5. Gnojenje $\mathrm{z}$ organskimi NPK gnojili $\mathrm{v}$ razmerju 3-2-1. Meritve povprečne višine travne ruše, celokupne višine travne ruše in povprečnega letnega dnevnega prirastka $\mathrm{v}$ višino so pokazale, da je bilo najboljše obravnavanje gnojenje $\mathrm{z}$ gnojili, ki počasi sproščajo hranila. Ruša, ki je bila gnojena $\mathrm{z}$ organskimi gnojili v razmerju 5-1-1, je dosegla enake največje vrednosti povprečne višine, celokupne višine in povprečnega letnega dnevnega prirastka $\mathrm{v}$ višino kot obravnavanje brez gnojenja. Izsledki so bili statistično značilni. Obravnavanje brez gnojenja je imelo najmanjše vrednosti ovrednotenih rastno-produkcijskih parametrov.

Ključne besede: travna ruša, gnojenje, organska gnojila, mineralna gnojila, rastno-produkcijski procesi

\footnotetext{
Ing. PhD., Slovak University of Agriculture in Nitra, Faculty of Agrobiology and Food Resources, Department of Grassland Ecosystems and Forage Crops, Tr. A. Hlinku 2, 94976 Nitra, Slovak Republic

2 prof. PhD., Slovak University of Agriculture in Nitra, Faculty of Agrobiology and Food Resources, Department of Grassland Ecosystems and Forage Crops, Tr. A. Hlinku 2, 94976 Nitra, Slovak Republic

3 doc. PhD., Slovak University of Agriculture in Nitra, Faculty of Agrobiology and Food Resources, Department of Grassland Ecosystems and Forage Crops, Tr. A. Hlinku 2, 94976 Nitra, Slovak Republic
} 


\section{INTRODUCTION}

Plant nutrition and turfs fertilizing have important position in system of caespestechnical measures (ways of exploiting and turf care) (Ondřej and Opatrná, 1997). Balanced and sufficient nutrition is a precondition for the turfs quality, their durability and resistance to disease and action of other stressors. Frequent mowing of ornamental and sport turfs demands fertilization (Svobodová, 1998).

For fertilizing of turfs various forms and types of fertilizers are used (Gregorová, 2001). Nitrogen fertilizers with nitrate $\left(\mathrm{NO}_{3}{ }^{-}\right)$, eg. ammonium nitrate are acting quickly, but they are quickly leached out from the soil. Nitrogen is flushed into groundwater or escapes as a gas compound into the atmosphere (Míka, 1991).

Slow release fertilizers (SRF) release nutrients slowly and uncontrolled (Wu et al., 2008). The greatest advantage is that the required dose of fertilizer is applied to a reduced numbers of applications compared to other forms of fertilizers (Magni et al., 2008).

In turf management use of classical organic fertilizers is not frequent (slurry, dung-water, etc.). The classical organic fertilizers are replaced by organic fertilizers which are in the dried form and do not contain live weed seeds and harmful microorganisms. Due to the gradual release of nutrients, fertilizer supply plant nutrients during the whole vegetation (Nardi et al., 2004; Rasmussen and Harold, 2008).

The aim of the experiment was to compare the influence of organic and inorganic fertilizers on selected traits of turf growth and production process under non-irrigated conditions.

\section{MATERIAL AND METHODS}

\subsection{Characteristics of experimental site}

In period $2012-2014$ a turf experiment located in moderate climatic zone of warm and dry area in Nitra (Slovak Republic) was conducted. Average annual temperature is $9.7^{\circ} \mathrm{C}$ and annual rainfall is $560 \mathrm{~mm}$ (Babošová and Noskovič, 2014). Weather conditions during vegetation periods are shown in Table 1.

Table 1: Weather condition on vegetation periods in $2012-2014$

\begin{tabular}{|c|c|c|c|c|c|c|c|c|c|c|c|}
\hline \multirow{2}{*}{ Year } & \multirow{2}{*}{ Indicator } & \multicolumn{8}{|c|}{ Month } & \multicolumn{2}{|c|}{$\begin{array}{l}\text { Vegetation } \\
\text { period }\end{array}$} \\
\hline & & III. & IV. & V. & VI. & VII. & VIII. & IX. & $\mathrm{X}$. & $\Sigma$ & $\varnothing$ \\
\hline \multirow{2}{*}{2012} & $\begin{array}{c}\varnothing \text { temperature } \\
\left({ }^{\circ} \mathrm{C}\right)\end{array}$ & 7.41 & 11.23 & 17.29 & 20.86 & 22.77 & 21.47 & 18.02 & 10.77 & - & 16.23 \\
\hline & $\Sigma$ rainfall $(\mathrm{mm})$ & 2.80 & 36.10 & 19.60 & 70.10 & 61.40 & 7.30 & 31.40 & 80.60 & 309.30 & - \\
\hline \multirow{2}{*}{2013} & $\begin{array}{c}\varnothing \text { temperature } \\
\left({ }^{\circ} \mathrm{C}\right)\end{array}$ & 3.20 & 12.10 & 15.50 & 19.30 & 22.70 & 21.80 & 14.70 & 12.10 & - & 15.18 \\
\hline & $\Sigma$ rainfall $(\mathrm{mm})$ & 106.20 & 20.40 & 77.80 & 46.70 & 2.10 & 73.90 & 60.00 & 30.50 & 417.60 & - \\
\hline \multirow{2}{*}{2014} & $\begin{array}{c}\varnothing \text { temperature } \\
\left({ }^{\circ} \mathrm{C}\right)\end{array}$ & 9.33 & 12.37 & 15.24 & 19.35 & 21.81 & 18.86 & 16.78 & 12.10 & - & 15.73 \\
\hline & $\Sigma$ rainfall $(\mathrm{mm})$ & 15.40 & 48.90 & 57.60 & 52.50 & 64.10 & 55.90 & 122.00 & 34.60 & 451.00 & - \\
\hline
\end{tabular}

Source: Department of Biometeorology and Hydrology, HLEF SUA in Nitra. Ø - average, $\Sigma$ - sum. 
The experiment was conducted on clay-loam fluvisol. In the autumn before the foundation of experiment we collected soil samples (app. $250 \mathrm{~g}$ ) from depth $0-200 \mathrm{~mm}$. The samples were analysed for:

- $\mathrm{N}_{\mathrm{t}}$ - Kjeldahl method,

- $\mathrm{P}-$ spectrophotometrically by phosphomolybdic method in the leachate by Mehlich III,

- $\mathrm{K}$ and $\mathrm{Ca}$ - flame-photometrically in the leachate by Mehlich III,
- $\mathrm{Mg}$ - spectrophotometrically in the leachate by Mehlich III,

- oxidizable carbon $\left(\mathrm{C}_{\mathrm{ox}}\right)$ - by Tjurin method in modification by Nikitin,

- $\mathrm{pH}$ - exchangeable in $\mathrm{KCl}$.

Soil chemical characteristics of the experimental site are documented in Table 2.

Table 2: Weather condition on vegetation periods in $2012-2014$

\begin{tabular}{|c|c|c|c|c|c|c|}
\hline $\mathrm{N}_{\mathrm{t}}$ & $\mathrm{P}$ & $\mathrm{K}$ & $\mathrm{Mg}$ & $\mathrm{Ca}$ & $\mathrm{C}_{\mathrm{ox}}$ & \multirow{2}{*}{$\mathrm{pH} / \mathrm{KCl}$} \\
\hline \multicolumn{5}{|c|}{$\mathrm{mg} \mathrm{kg}^{-1}$} & $\mathrm{~g} \mathrm{~kg}^{-1}$ & \\
\hline 1823.2 & 58.3 & 336 & 541 & 6067 & 7.7 & 6.78 \\
\hline
\end{tabular}

\subsection{Characteristics of experiment}

The experiment was established in early October 2011. We used turf mixture designed for low slowly growing turfs with following composition: Lolium perenne L. (30\%), Festuca rubra L. (50\%) and Festuca ovina L. (20\%).

Experimental plots area was $2.4 \mathrm{~m}^{2}$ and each treatment was in 3 random replications.

In the experiment 5 treatments were used:

1. Without fertilizing („Control“),
2. Turf fertilizer NPK $15-3-8(+3 \mathrm{MgO}+0.8$ $\mathrm{Fe}+18 \mathrm{~S}$ ) („Turf fertilizer"),

3. Slow release fertilizer NPK 14-5-14 $(+4$ $\mathrm{CaO}+4 \mathrm{MgO}+7 \mathrm{~S})\left(\right.$, $\left.\mathrm{SRF}^{\prime \prime}\right)$,

4. Organic fertilizer NPK 5-1-1 (,OF 1“),

5. Organic fertilizer NPK 3-2-1 (,OF 2“),

For the recommended $\mathrm{N}$ dose of fertilizer the value $18 \mathrm{~g} \mathrm{~m}^{-2}$ was taken, which meets the requirements for intensively used turfs (Svobodová, 2004).

System of fertilizing is presented in Table 3.

Table 3: System of fertilizing

\begin{tabular}{|c|c|c|c|c|c|}
\hline \multirow{2}{*}{$\begin{array}{c}\text { Type of fertilizer (number of } \\
\text { applications per year) }\end{array}$} & $\begin{array}{c}\text { Yearly dose } \\
\left(\mathrm{g} \mathrm{m}^{-2}\right)\end{array}$ & \multicolumn{4}{|c|}{ Date of application } \\
\hline & & $\begin{array}{c}\text { Beginning } \\
\text { of vegetation }\end{array}$ & $\begin{array}{c}\text { Around } \\
20.6 .\end{array}$ & Half of July & Half of August \\
\cline { 3 - 6 } & & \multicolumn{3}{|c|}{ Dose of fertilizer to variant $\left(\mathrm{g} \mathrm{m}^{2}{ }^{2}\right)$} \\
\hline Turf fertilizer (3x) & 120 & 40 & 40 & & 40 \\
\hline SRF (2x) & 128,6 & 64,3 & & 64,3 & \\
\hline OF 1 (1x) & 360 & 360 & & & \\
\hline OF 2 (1x) & 600 & 600 & & & \\
\hline
\end{tabular}




\subsection{Characteristics of fertilizers used in the} experiment

Turf fertilizer $15-3-8(+3 \mathrm{MgO}+0.8 \mathrm{Fe}+18 \mathrm{~S})$ is the granulated fertilizer intended for use for turfs throughout the year in the form for multiple fertilization (three-fivefold) during the growing season. Nitrogen is in the ammonium form.

SRF NPK 14-5-14 $(+4 \mathrm{CaO}+4 \mathrm{MgO}+7 \mathrm{~S})$ is a complex NPK fertilizer containing urea formaldehyde component as a source of nitrogen enriched with micronutrients. Part of major NPK nutrients is founded in fast-dissolving form.

OF 5-1-1 content is comprising $\mathrm{C}, \mathrm{H}, \mathrm{O}, \mathrm{N}, \mathrm{P}, \mathrm{K}$, $\mathrm{Ca}, \mathrm{Mg}, \mathrm{S}, \mathrm{Fe}$ etc., in the form of organic components of the starch material from the milled cereals $(30 \%)$, enriched hydrolyzate of whey $(30 \%)$, lignocelluloses raw material from wood processing (30\%), by hydrolysis of whey enriched $(30 \%)$ and in $10 \%$ mineral constituent zeolite of sodium aluminium silicate. Philosophy of this fertilizer is unlike mineral fertilizers aimed at improving the carbon balance.

OF 3-2-1 is produced by modern technology from natural materials without the use of chemicals and preservatives. Production procedure at high temperature leads to inactivation of pathogens and weed seeds. This fertilizer is characterized as highquality organic fertilizer with gradual release of the main nutrients and essential trace elements. Its high biological value is increased due to harmless processing, content balance, easy handling and hygiene applications in practice. Compared with manure it constitutes a modern compensation for of manure.

\subsection{Monitored parameters and analysis}

Experiment was realized under non-irrigated conditions. When turf reached height of approximately $80-100 \mathrm{~mm}$, it was mowed to height $50 \mathrm{~mm}$. The turf height $(\mathrm{mm})$ was determined as an average of 10 measurements in plots before each mowing. We used for the measurement ruler. Production of above-ground phytomass $\left(\mathrm{g} \mathrm{m}^{-2}\right)$ was determined by sampling the above-ground phytomass by means of accumulation scissors from the surface of $0.1 \times 1 \mathrm{~m}$ and subsequently dried at $105^{\circ} \mathrm{C}$.

The annual average daily gain of height $\left(\mathrm{mm} \mathrm{day}^{-1}\right)$ was calculated according to the formula:

\section{The average daily gain of height = Q haight gf manting (mm)- $80 \mathrm{~mm}$ number ot scaretion dezz}

The annual average daily gain of height $=$ the rum of avarage dally rating of beight

number of the avarage datly gating of bal wht

The annual average daily gain of mass $\left(\mathrm{g} \mathrm{m}^{-2}\right.$ day $\left.^{-1}\right)$ was calculated according to the formula:

The average daily gain of phytomass = Oprodustion onmawiag $(\mathrm{sm})$

number of sceretion deys

The annual average daily gain of phytomass = the sum of ayarage dally gating of mass

number of the swerseg dsily galnz of $m s n$

\subsection{Statistical analysis}

Results were statistically evaluated by the Analysis of Variance (ANOVA - Multiple Range Tests, Method: 95.0 percent LSD) using statistical software STATISTICA 7.1 (Stat Soft. Inc. 2007).

\section{RESULTS AND DISCUSSION}

\subsection{The average height of turf}

The average height of turf is indicated in Table 4 . The highest turfs were fertilized by Turf fertilizer $(103.59 \mathrm{~mm})$ and SRF $(105.41 \mathrm{~mm})$ in 2012. Treatment "OF 2" (94.66 mm) was lower in comparison to the Control $(95.99 \mathrm{~mm})$. Turf fertilized OF 1 reached the average height of turf $99.25 \mathrm{~mm}$. Comparing the values of standard deviation $(\delta)$ showed that the effect of the fertilizer SRF $(\delta=1.59)$ on turf is more evenly developed as treatments fertilized by Turf fertilizer $(\delta=1.68)$, OF $1(\delta=1.71)$, and OF 2 (1.83). The least balanced growth was at Control $(\delta=2.16)$. 
We registered increase of the average height on turfs fertilized by Turf fertilizer, SRF and OF 1 $(115.59-120.05 \mathrm{~mm})$ in the second year (2013). There was also higher variability of measured values $(1.97$ - 3.49) in compare to the other variants. The sharp decline reached Control (72.03 $\mathrm{mm})$.

In the last evaluated year (2014) again higher average height of turf was reached by application
Turf fertilizer, SRF and OF $1(112.10-118.79$ $\mathrm{mm})$. Treatment "OF 2" didn't reach the average height $100 \mathrm{~mm}$ not even in 2014.

The values of the average turf height for the whole period (2012 - 2014) fertilized by organic and inorganic fertilizers were statistically higher than Control. The smallest growth had turf fertilized by OF $1(\delta=2.93)$. Between 2012 and 2014 we found statistically significant effect on the average height of turf.

Table 4: The average height of turf

\begin{tabular}{|c|c|c|c|c|c|c|c|c|}
\hline \multirow{2}{*}{ Year/variant } & \multicolumn{2}{|c|}{2012} & \multicolumn{2}{c|}{2013} & \multicolumn{2}{c|}{2014} & \multicolumn{2}{c|}{$2012-2014$} \\
\cline { 2 - 9 } & $\begin{array}{c}\bar{x} \text { height } \\
(\mathrm{mm})\end{array}$ & $\delta$ & $\begin{array}{c}\bar{x} \text { height } \\
(\mathrm{mm})\end{array}$ & $\delta$ & $\begin{array}{c}\bar{x} \text { height } \\
(\mathrm{mm})\end{array}$ & $\delta$ & $\begin{array}{c}\bar{x} \text { height } \\
(\mathrm{mm})\end{array}$ & $\delta$ \\
\hline Control & 95.99 & 2.16 & 72.03 & 1.30 & 83.24 & 1.52 & $83.75^{\mathrm{b}}$ & 2.02 \\
\hline Turf fertilizer & 103.59 & 1.68 & 119.78 & 2.03 & 112.10 & 2.30 & $111.82^{\mathrm{a}}$ & 2.13 \\
\hline SRF & 105.41 & 1.59 & 115.59 & 1.97 & 118.79 & 2.05 & $113.26^{\mathrm{a}}$ & 1.99 \\
\hline OF 1 & 99.25 & 1.71 & 120.05 & 3.49 & 117.45 & 2,87 & $112.25^{\mathrm{a}}$ & 2.93 \\
\hline OF 2 & 94.66 & 1.83 & 94.97 & 1.76 & 97.94 & 1.96 & $95.86^{\mathrm{c}}$ & 1.86 \\
\hline$\varnothing$ & $80.58^{\mathrm{A}}$ & - & $104.48^{\mathrm{AB}}$ & - & $105.90^{\mathrm{B}}$ & - & - & - \\
\hline
\end{tabular}

Different index (a, A, b, B, c) means statistically significant differences within column (Fisher LSD test, $\alpha=0.05$ ), $\delta$ - standard deviation, $\bar{x}$, - arithmetic mean, $\varnothing$ - mean.

\subsection{Total height of turf}

The results of total turf height are presented on Figure 1. Turfs fertilized by inorganic fertilizers Turf fertilizer $(463.70 \mathrm{~mm})$ and SRF $(481.00 \mathrm{~mm})$ had a high growth in 2012. Treatments with application of organic fertilizers grew more slowly $(370.60$ and $409.70 \mathrm{~mm})$ than Control $(412.20 \mathrm{~mm})$. In this year we observed a negative effect of rainfall deficiency on the turf growth (Table 1). Lack of water affected the functional manifestations of the plants and realization of their growth-production process (Kostrej et al., 2000; Brestič and Olšovská, 2001; Brestič et al., 2008).

We observed marked increase of the total height of turf at all variants in the following year (2013). The exception was control where total turf height decreased $(198.30 \mathrm{~mm})$. Maximum turf height was reached when fertilized by OF $1(630.47 \mathrm{~mm})$.

The values of total turf height again increased at all treatments in 2014. The biggest increase was observed on turf fertilized by SRF (about $166.34 \mathrm{~mm}$ ). Conversely, markedly less than it was on the variant with application Turf fertilizer (about $55 \mathrm{~mm}$ ).

In years 2012 - 2014 the most intensively grew turfs fertilized by Turf fertilizer $(591.57 \mathrm{~mm})$, OF $1(594.06 \mathrm{~mm})$ and SRF $(609.33 \mathrm{~mm})$. Statistical evaluation showed that fertilization with these fertilizers had significant effect on the total height of fertilized turfs compared with control. 


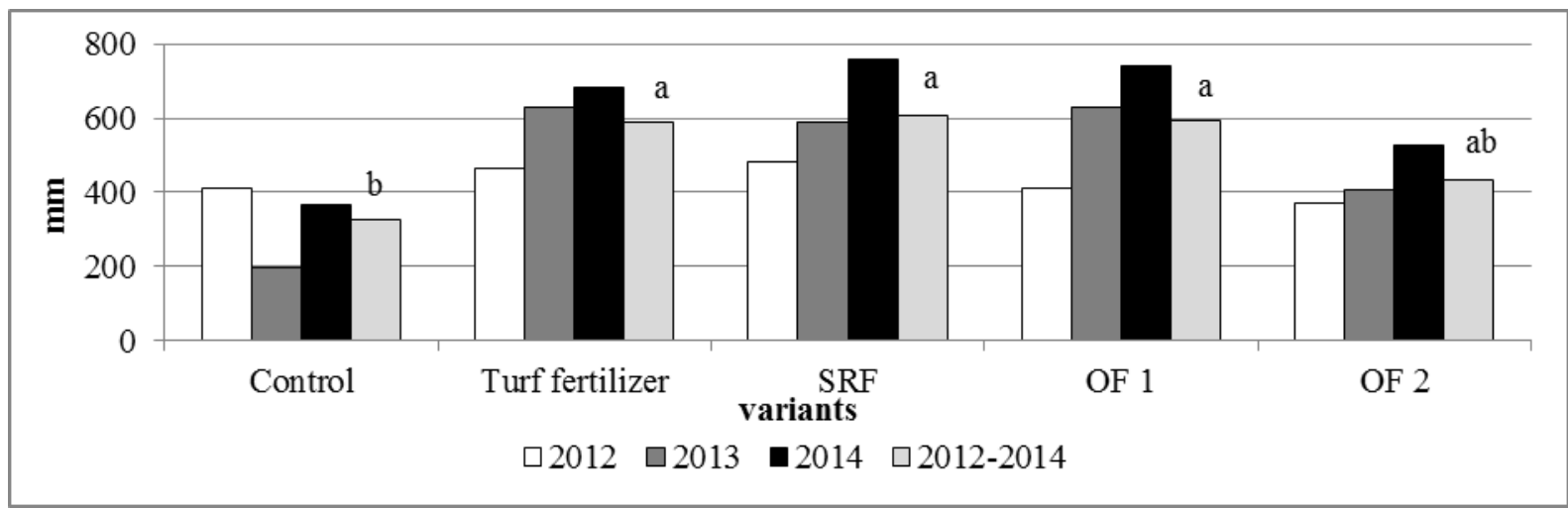

Different index $(a, b)$ means statistically significant differences within column (Fisher LSD test, $\alpha=0.05)$.

Figure 1: Total height of turf

\subsection{The annual average daily gain of height}

The development of the average annual daily gain of height in 2012 is presented on Figure 2. The highest intensity of growth (more than $5 \mathrm{~mm}$ day $^{-1}$ ) was observed on turfs with application Turf fertilizers (more than $5.18 \mathrm{~mm}$ day $^{-1}$ ), SRF $\left(5.55 \mathrm{~mm} \mathrm{day}{ }^{-1}\right)$ and OF $1\left(5.09 \mathrm{~mm} \mathrm{day}{ }^{-1}\right)$. Comparison of the average daily gain of height values with the Descriptor for Poaceae (Ševčíková et al., 2002) showed that turfs had "very fast" growth, i.e. achieved 1 point on the scale, where 1 is the worst and 9 is the best rating level of evaluated characteristics. "Moderate" growth (i.e. 3 points according to this scale) had control treatment, turfs fertilized by Turf fertilizer and OF 2. It is considered positive from the point of view of grass turf management (Turgeon, 2002; Cagaš and Macháč, 2005).

In the second year of monitoring (2013) the growth in treatments "Turf fertilizer", "SRF" and "OF 1" was even faster (until $6.35 \mathrm{~mm} \mathrm{day}^{-1}$ ) than in 2012. We consider a possible gradual release of nutrients in the environment during the whole season (Gregorová 2001; Svobodová, 2003), when the weather conditions were better than in the previous year (Table 1). Similar conclusion in turf experiments reached Zhang and Nyborg (1998) too. They found that better weather conditions improved the release of nutrients from these fertilizers. This results in improving growthproduction process of turf. Slowly developed turf with application OF 2 and control. According to the Descriptor for Poaceae (Ševčíková et al., 2002), can be argued that turfs fertilized by Turf fertilizer, SRF and OF 1 reached "very fast" growth.

In 2014 we found a decrease in the rate of turfs growth. The most remarkable change occurred in the treatment "Turf fertilizer" (about $2.55 \mathrm{~mm}$ day" $\left.{ }^{1}\right)$. The most intensive growth had turfs fertilized by SRF $\left(4.17 \mathrm{~mm} \mathrm{day}^{-1}\right)$ and OF $1\left(4.47 \mathrm{~mm}^{-}\right.$day $^{-}$ $\left.{ }^{1}\right)$. According to the Descriptor for Poaceae (Ševčíková et al., 2002), we may evaluate these turfs as "fast" growing. Other fertilization treatments could be evaluated as "moderate" growing.

Comparing the monitored years 2012 - 2014, we found the highest annual average daily height gain on turfs fertilized with Turf fertilizer $(5.11 \mathrm{~mm}$ day $\left.^{-1}\right)$, SRF (5.20 mm day $\left.{ }^{-1}\right)$ and OF 1 (5.26 mm day $\left.^{-1}\right)$. Treatment "OF 2" had lower average height daily gain $\left(3.86 \mathrm{~mm} \mathrm{day}^{-1}\right)$. The lowest growth rate was observed in Control $\left(2.78 \mathrm{~mm} \mathrm{day}^{-1}\right)$. These findings were not statistically significant. 
The comparison of organic and inorganic fertilizers influence on selected indicators of turf growth-production process

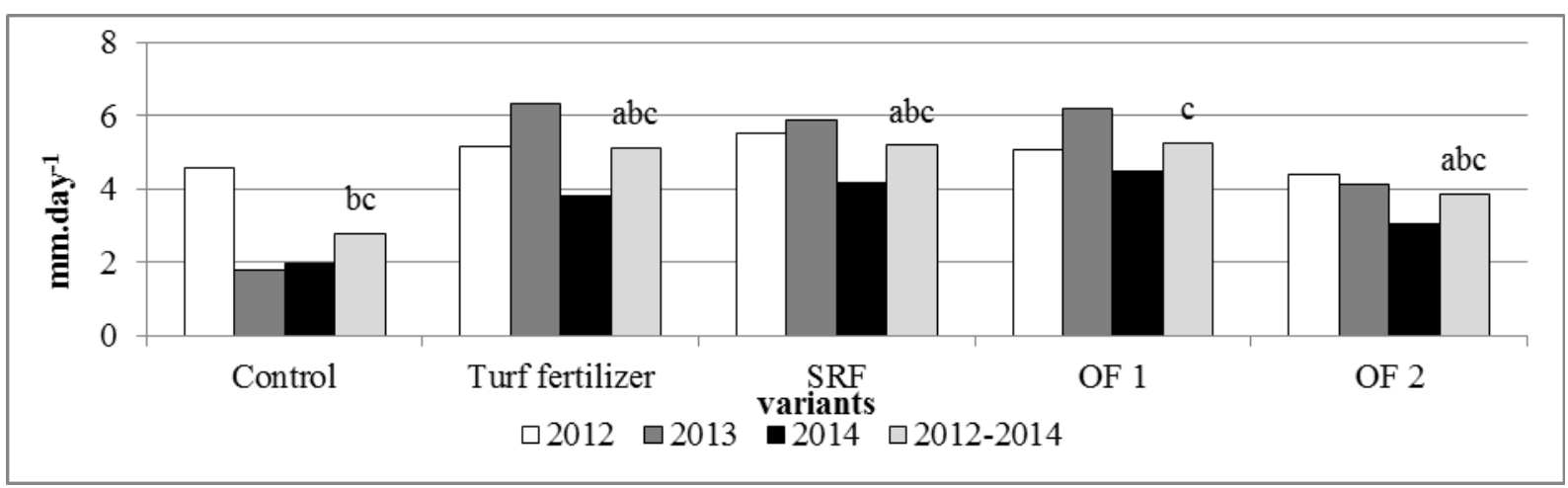

Different index (a, b, c) means statistically significant differences within column (Fisher LSD test, $\alpha=0.05$ ).

Figure 2: The annual average daily height gain

\subsection{The average of above-ground dry phytomass}

The values of the average of dry above-ground phytomass (Table 5) seems that turfs fertilized by inorganic fertilizers Turf fertilizer and SRF produced about $2.11-3.50 \mathrm{~g} \mathrm{~m}^{-2}$ more phytomass as control. Treatments with application of organic fertilizers had the average of dry above-ground phytomass smaller than $30 \mathrm{~g} \mathrm{~m}^{-2}$. The smallest above-ground phytomass created control $(30.81 \mathrm{~g}$ $\mathrm{m}^{-2}$ ), which was also characterized by lowest variability of phytomass production $(\delta=1.4)$. Conversely the variant of application, in which the highest production of above-ground phytomass was observed, was the least suitable from this perspective (Bigelow and Walker, 2005).

Relatively high production of phytomass was characterized for variant fertilized by OF 1 $\left(44.44 \mathrm{~g} \mathrm{~m}^{-2}\right)$ in 2013. Turfs with application of inorganic fertilizers had almost identical average of dry above-ground phytomass $\left(38.68-38.96 \mathrm{~g} \mathrm{~m}^{-}\right.$ $\left.{ }^{2}\right)$. The least productive treatment was OF 2 $\left(27.71 \mathrm{~g} \mathrm{~m}^{-2}\right)$ and control $\left(15.57 \mathrm{~g} \mathrm{~m}^{-2}\right)$. Control had also the lowest variability of phytomass production $(\delta=1.28$ and 1.72$)$.

Variants fertilized by inorganic fertilizers and OF 1 reached almost identical production of phytomass $\left(30.47-32.40 \mathrm{~g} \mathrm{~m}^{-2}\right)$ in the last evaluated year (2014). The least productive were treatment with application OF $2\left(23.97 \mathrm{~g} \mathrm{~m}^{-2}\right)$ and control $(12.22 \mathrm{~g}$ $\mathrm{m}^{-2}$ ), which also had the lowest variability of production of aboveground phytomass $(\delta=0.79$ and 1.64).

The average of years $2012-2014$ seems that the average of dry above-ground phytomass on fertilized turfs as control was statistically significant. Approximately the same production of phytomass produced treatments fertilized by inorganic fertilizers and OF 1 (34.55 and $34.92 \mathrm{~g}$ $\mathrm{m}^{-2}$ ). Turf with application of OF 2, compared to other fertilized turfs, produced less above-ground phytomass (about $7.65-8.02 \mathrm{~g} \mathrm{~m}^{-2}$ ). Treatments fertilized by organic fertilizers were characterized by the lowest and highest variability of phytomass $(\delta=1.63$ and 2.57). Given the objective of turf growing, which is to achieve and maintain suitable turf, e. g. adequate density, balanced colour, uniformity, recuperative capacity without achieving high production of aboveground phytomass (Gregorová, 2001; Turgeon 2002) the variants Control, SRF and OF 2 were positively assessed. For the year 2014 was proved statistically significant effect of treatments on the average of dry above-ground phytomass. 
Peter HRIC et al.

Table 5: The average of dry above-ground phytomass

\begin{tabular}{|c|c|c|c|c|c|c|c|c|}
\hline \multirow{2}{*}{ Year/variant } & \multicolumn{2}{|c|}{2012} & \multicolumn{2}{c|}{2013} & \multicolumn{2}{c|}{2014} & \multicolumn{2}{c|}{$2012-2014$} \\
\cline { 2 - 9 } & $\begin{array}{c}\bar{x} \\
\text { phytomass } \\
\left(\mathrm{g} \mathrm{m}^{-2}\right)\end{array}$ & $\delta$ & $\begin{array}{c}\bar{x} \\
\text { phytomass } \\
\left(\mathrm{g} \mathrm{m}^{-2}\right)\end{array}$ & $\delta$ & $\begin{array}{c}\bar{x} \\
\text { phytomass } \\
\left(\mathrm{g} \mathrm{m}^{-2}\right)\end{array}$ & $\delta$ & $\begin{array}{c}\bar{x} \\
\text { phytomass } \\
\left(\mathrm{g} \mathrm{m}^{-2}\right)\end{array}$ & $\delta$ \\
\hline Control & 30.81 & 1.24 & 15.57 & 1.28 & 12.22 & 0.79 & $19.53^{\mathrm{b}}$ & 1.36 \\
\hline Turf fertilizer & 34.31 & 1.93 & 38.96 & 1.95 & 30.47 & 2.43 & $34,58^{\mathrm{a}}$ & 2.14 \\
\hline SRF & 32.92 & 1.26 & 38.68 & 2.34 & 32.05 & 1.75 & $34,55^{\mathrm{a}}$ & 1.83 \\
\hline OF 1 & 27.93 & 1.46 & 44.44 & 3.51 & 32.40 & 2.21 & $34.92^{\mathrm{a}}$ & 2.57 \\
\hline OF 2 & 29.02 & 1.52 & 27.71 & 1.72 & 23.97 & 1.64 & $26.90^{\mathrm{c}}$ & 1.63 \\
\hline$\varnothing$ & $31.0^{\mathrm{A}}$ & - & $38.21^{\mathrm{A}}$ & - & $26.22^{\mathrm{B}}$ & - & & - \\
\hline
\end{tabular}

Different index (a, A, b, B, c) means statistically significant differences within column (Fisher LSD test, $\alpha=0.05$ ), $\delta$ - standard deviation, $\bar{x}$ - arithmetic mean, $\varnothing-$ mean.

\subsection{Total production of dry above-ground phytomass}

The total production of dry above-ground phytomass (2012) was the highest on treatments fertilized by inorganic fertilizers Turf fertilizer $\left(308.80 \mathrm{~g} \mathrm{~m}^{-2}\right)$ and SRF $\left(296.30 \mathrm{~g} \mathrm{~m}^{-2}\right)$. Also Cagaš et al. (2011) found out in turf experiments that at different dose of nitrogen higher production of phytomass was achieved on turf fertilized by slow release fertilizer than on turf fertilized by longacting fertilizer. The smallest production had treatments with application of organic fertilizers $\left(251.40-261.20 \mathrm{~g} \mathrm{~m}^{-2}\right)$.

The lowest production had control $\left(140.20 \mathrm{~g} \mathrm{~m}^{-2}\right)$ in the second year (2013). Relatively higher production was observed also on treatment "OF 2" $\left(249.43 \mathrm{~g} \mathrm{~m}^{-2}\right)$. Approximately $350 \mathrm{~g} \mathrm{~m}^{-2}$ of aboveground phytomass produced turfs with application of inorganic fertilizers. Treatment "SRF" reached lower production as treatment "Turf fertilizer". This finding was not confirmed in an experiment carried out by Bilgili and Açikgöz (2011). The highest total production of dry above-ground phytomass had turf with application of OF 1 (399.97 $\left.\mathrm{g} \mathrm{m}^{-2}\right)$.

Fertilized treatments, without turf fertilized OF 2 $\left(263.67 \mathrm{~g} \mathrm{~m}^{-2}\right)$, produced phytomass bigger than $300 \mathrm{~g} \mathrm{~m}^{-2}$ in 2014. Control treatment had production of above-ground phytomass $134.37 \mathrm{~g}$ $\mathrm{m}^{-2}$.

Comparison of total production values of dry above-ground phytomass (2012 - 2014) with Descriptor for Poaceae (Ševčíková et al., 2002), has shown that all evaluated treatments were characterized from "very low" until "low" production of phytomass $\left(250-400 \mathrm{~g} \mathrm{~m}^{-2}\right)$. The exception was control which is characterized by "very low" production of phytomass $\left(<250 \mathrm{~g} \mathrm{~m}^{-2}\right)$. Improvement in production of turfs fertilized by inorganic fertilizers and OF 1 was compared with control, and the difference was statistically significant. Treatment "SRF" was one of the most productive in our experiment. However, this is not matched with the statement of Lošák and Ševčíková (2012), who in their experiment after using slow release fertilizer recorded the lowest production of above-ground phytomass. 
The comparison of organic and inorganic fertilizers influence on selected indicators of turf growth-production process

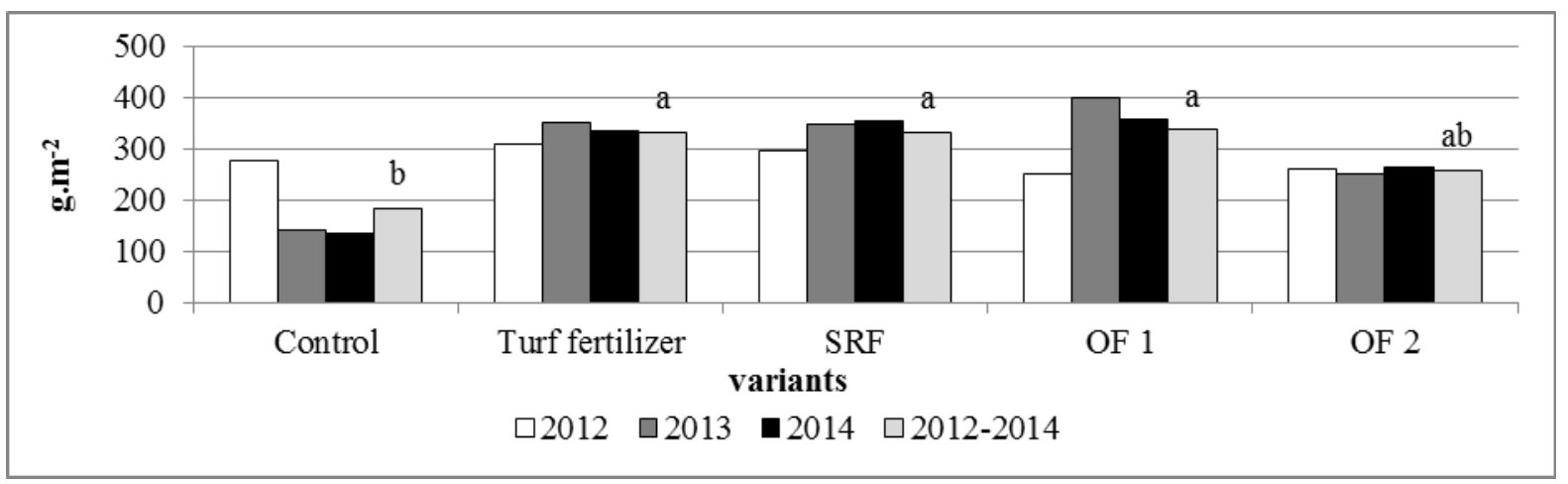

Different index $(a, b)$ means statistically significant differences within column (Fisher LSD test, $\alpha=0.05$ ).

Figure 3: Total production of dry above-ground phytomass

\subsection{The annual average daily phytomass gain}

Analysis of the annual average daily gain of aboveground phytomass (2012) (Figure 4) was observed the highest on treatments fertilized by inorganic fertilizers Turf fertilizer $\left(3.43 \mathrm{~g} \mathrm{~m}^{-2}\right.$ day $\left.^{-1}\right)$ and SRF (3.31 $\mathrm{g} \mathrm{m}^{-2}$ day $\left.^{-1}\right)$. Martincová (2007) found out increasing of phytomass production on treatment fertilized by slow release fertilizer in drier seasons as on treatments with long-acting forms of fertilizers. This claim was not confirmed in our experiment. Conversely the lowest annual average daily phytomass gain was achieved on turfs fertilized by organic fertilizers OF $1\left(2.94 \mathrm{~g} \mathrm{~m}^{-2}\right.$ day $\left.^{-1}\right)$, OF $2\left(2.68 \mathrm{~g} \mathrm{~m}^{-2}\right.$ day $\left.^{-1}\right)$ and control $(2.95 \mathrm{~g}$ $\mathrm{m}^{-2}$ day $^{-1}$ ).

In the following year 2013 the most productive were treatments fertilized by inorganic fertilizers Turf fertilizer $\left(2.73 \mathrm{~g} \mathrm{~m}^{-2}\right.$ day $\left.^{-1}\right)$, SRF $\left(3.02 \mathrm{~g} \mathrm{~m}^{-2}\right.$ day $\left.^{-1}\right)$ and OF 1 (3.96 $\mathrm{g} \mathrm{m}^{-2}$ day $\left.^{-1}\right)$. The lowest production we observed on control $\left(1.29 \mathrm{~g} \mathrm{~m}^{-2}\right.$ day $\left.{ }^{1}\right)$.
In 2014 the most productive treatments were again those fertilized by inorganic fertilizers $\left(2.68 \mathrm{~g} \mathrm{~m}^{-2}\right.$ day $^{-1}$ and $2.89 \mathrm{~g} \mathrm{~m}^{-2}$ day $\left.^{-1}\right)$ and OF $1\left(3.21 \mathrm{~g} \mathrm{~m}^{-2}\right.$ day $\left.^{-1}\right)$. Turf with application of OF 2 produced about $50 \%$ more above-ground phytomass as control. This increase wasn't considerable as in experiment of Sloboda (2000), who observed increase in phytomass for about $294.6 \%$, also Bošanská (1999) found out using OF 2 fertilizer increased production for about $33 \%$ versus control.

In comparing the monitored years 2012 - 2014, we found yearly reduction of annual average daily phytomass gain. The treatment OF 1 , where the production of phytomass in 2013 was about $1.02 \mathrm{~g}$ $\mathrm{m}^{-2}$ day $^{-1}$ was higher than in 2012. The most remarkable decline in production was seen on control (about $1.66 \mathrm{~g} \mathrm{~m}^{-2}$ day $^{-1}$ ). Relatively balanced average of above-ground phytomass gain was on turf with application of SRF. The annual average daily phytomass gain increased on all fertilized treatments compared with control. Statistically significant effect was recorded on turf fertilized by OF 1 . 


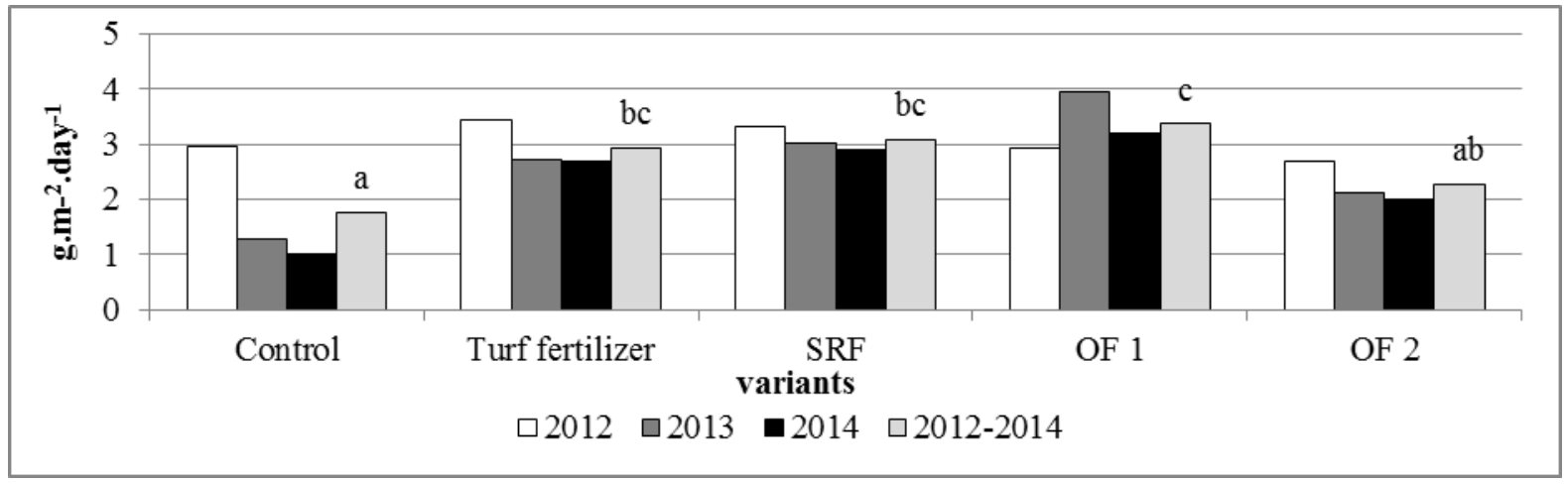

Different index $(a, b, c)$ means statistically significant differences within column (Fisher LSD test, $\alpha=0.05)$.

Figure 4: The annual average daily phytomass gain

\section{CONCLUSION}

There was observed the influence of organic and inorganic fertilizers on selected characteristics of turf growth-production process. The highest turf height and production of above-ground phytomass were gained by effect of Turf fertilizer 15-3-8 $(+3 \mathrm{MgO}+0.8 \mathrm{Fe}+18 \mathrm{~S})$, slow release fertilizer $14-$ $5-14(+4 \mathrm{CaO}+4 \mathrm{MgO}+7 \mathrm{~S})$ and organic fertilizer 5-1-1. Organic fertilizer 3-2-1 and control treatment reached lower parameters of turf growthproduction process. Given the objective of turf growing, which is to achieve and maintain suitable turf, i.e. adequate density, balanced colour, uniformity, recuperative capacity without achieving high production of aboveground phytomass, the treatments implemented were appropriate. Treatments fertilized by slow release fertilizer $14-5-14 \quad(+4 \mathrm{CaO}+4 \mathrm{MgO}+7 \mathrm{~S})$ and organic fertilizer 5-1-1 had the most balanced growth and the highest production of turf aboveground phytomass in comparison with others treatments.

\section{ACKNOWLEDGEMENTS}

The contribution was supported by grant VEGA 1/0687/14

\section{REFERENCES}

Babošová, M., Noskovič, J. (2014). Kvalita atmosférických zrážok v oblasti mesta Nitra-Dolná Malanta. (Quality of atmospheric precipitation in the city of Nitra-Dolna Malanta). Nitra,:SPU.

Bigelow, C.A., Walker, K. S. (2005). Kentucky bluegrass response to three autumn applied urea. C05 Turfgrass Science, ASA-CSSA Anual Meetings. Salt Lake City, 85 - 90.

Bilgili, U., Açikgöz, E. (2011). Efect of slow-release fertilizers on turf quality in a turf mixture. Turkish Journal of Field Crops, 16 (2), 130 - 136.
Bošanská, M. (1999). Biokompost Veget-univerzálne organické hnojivo. (Biocompost Veget-universal organic fertilizer). Agrochémia, 39 (3), p. 21.

Brestič, M., Olšovská, K. (2001). Vodný stres rastlín: príčiny, dôsledky, perspektívy. (Plant water stress: causes, consequences, perspectives). Nitra: SPU.

Brestič, M., Olšovská, K., Hauptvogel, P. (2008). Život rastlín $\mathrm{v}$ meniacich sa podmienkach prostredia: evolučná perspektíva pre 21. storočie. (Plant life in changing environmental conditions: an evolutionary perspective for the 21st century). Brno: Tribun EU s.r.o. 
Cagaš, B., Macháč, J. (2005). Ochrana trávníků proti chorobám, škůdcům, plevelům a abiotickému poškození. (Protecting turf against diseases, pests, weeds and abiotic damage). České Budějovice: Kurent, s.r.o.

Cagaš, B., Ševčíková, M., Hrabě, F., Straková, M., Hejduk, S., Janků, L., Knot, P., Lošák, M., Straka, J. (2011). Zakládaní a ošetřování krajinných trávniků a travnatých ploch veřejné zelene: certifikovaná metodika. (Establishing and maintenance of turfs and grassy areas a public greenery: certified methodology). Brno: Svaz zakládání a údržby zeleně.

Gregorová, E. (2001). Trávnikárstvo. (Turfgrass management). Nitra: SPU Ochrana biodiverzity 31 .

Kostrej, A, Brestič, M., Danko, J., Jureková, Z., Kostrej, A., Olšovská, K. (2000). Funkčné parametre produkčného procesu obilnín $\mathrm{v}$ meniacich sa podmienkach prostredia. (Functional parameters of the production process of cereals changing environmental conditions). Nitra: Agroinštitút, tlačiarenské stredisko.

Lošák, M., Ševčíková. M. (2012). Vliv hnojení na produkci nadzemní a podzemní biomasy neprodukčných trávníků. (The influence of fertilization on the production of above and below ground biomass non-production turfs). Aktuální témata v pícninářství a trávnikářství (Sbornik príspevků z odborného semináře konaného v Praze 5. prosince 2012), Praha: ČZU. 56 - 60.

Magni, S., Foschi, L., Piccotino, D., Miele, S. (2008). Nitrogen availability of different slow release fertilizers as determined by incubation in a sand based growing medium. $1^{\text {st }}$ European turfgrass society conference $19^{\text {th }}-20^{\text {th }}$ may, Pisa (Italy). 121 122.

Martincová, J. (2007). Pôsobenie rýchlo rozpustných hnojív a pomaly rozpustných hnojív na úrodu sušiny kostravy trst'ovníkovitej (Festuca arundinacea SCHREB.). (The action fast soluble fertilizers and slow release fertilizers for dry matter yield (Festuca arundinacea SCHREB.)). Súčastnost' a perspektívy krmovinárskeho výskumu a vzdelávania v multifunkčnom využivani krajiny (zbornik referátov). Nitra: SPU. 164 - 167.
Míka, V. 1991. Požadavky na hnojiva pro okrasné trávníky. (Requirements for fertilizer for ornamental turfs). Agrochémia, 31 (8), p. 174 176.

Nardi, S., Morari, F., Berti, A., Tosoni, M., Giardini, L. 2004. Soil organic mater properties after 40 years of different use of organic and mineral fertilizers. European Journal of Agrononomy, 21: 357 - 367. Doi: 10.1016/j.eja.2003.10.006

Ondřej, J., Opatrná, M. (1997). Trávníky a okrasné trávy. (Turfs and ornamental grasses). Praha: BRIO spol. s.r.o.

Sloboda, J. (2000). Veget-nové organické hnojivo. (Veget-new organic fertilizer). Trávniky 2000 (zborník z III. Slovenskej trávnikárskej konferencie), SPU Nitra- kongresové centrum, $69-$ 72.

Rasmussen, P. E., Harold, P. C. (2008). Long-term impacts of tillage, fertilizer, and crop residue on soil organic matter in temperate semiarid regions. Advances in Agronomy, 45 (5), 93 - 97.

Svobodová, M. (1998). Trávníky. (Turfs). Praha: ČZU.

Svobodová, M. (2003). Trávníky. (Turfs). Praha: ČZU.

Svobodová, M. (2004). Trávnik. (Turfs). Praha: Grada Publishing a.s.

Statistica program/documentation: Stat Soft. Inc. 2007. STATISTICA (data analysis software system). Version 7.1. www.statsoft.cz.

Ševčíková, M., Šrámek, P., Faberová, I. (2002). Klasifikátor - Trávy (Poaceae L.). (Descriptor for Poaceae L. Family). Zubří: OSEVA PRO s.r.o.

Turgeon, A. J. (2002). Turfgrass management. Prentice Hall Upper Saddle River, New Jersey, $6^{\text {th }}$ edition.

Zhang, M., Nyborg, M. (1998). Comparison of Controlled-release Nitrogen Fertilizers on Turfgrass in a Moderate Temperature Area. HortScience, 33 (7), 1203 - 1206.

Wu, L., Liu, M., Liang, R. (2008). Preparation and properties of a double-coated slow-release NPK compound fertilizer with superabsorbent and water-retention. Bioresource technology, 99 (3), 547 - 554. Doi: 10.1016/j.biortech.2006.12.027 